\title{
DIABETES INSIPIDUS FOLLOWING CLOSED HEAD INJURY
}

\author{
BY \\ R. J. PORTER and R. A. MILLER \\ -From the Department of Neurology, Radcliffe Infirmary, Oxford \\ (RECEIVED MAY 25, 1948)
}

Diabetes insipidus is a rare disease and it is a very uncommon sequel of head injury. Fitz (1914) found that the incidence of the disease attributable to any cause was fourteen cases per hundred thousand admissions to a general hospital, and Rowntree (1924) found thirteen cases per hundred thousand admissions to the Mayo Clinic. Rabinowitch (1921) found one case of diabetes insipidus. among fifty thousand admissions to a general hospital. In only two of fifty-six cases reported by Rowntree (1924) and two, or possibly three, of forty-two cases reported by Jones (1944) was the diabetes insipidus due to head injury. Rand and Patterson (1937) have stressed the rarity of posttraumatic diabetes insipidus by stating that no case occurred in one hundred and fifty thousand admissions to a neurosurgical unit.

Kahler (1886) reported twenty-six cases of diabetes insipidus following head injury, and Rand and Patterson (1937) recorded six cases; the majority of reports on the clinical features of the condition, however, have been based on one or two cases. Fink (1928), Turner (1928), and Warkany and Mitchell (1939) have reviewed the literature, and Riddoch (1938), Symonds (1943), and Rowbotham (1945) have recorded their impressions. It is the most common hypothalamic disorder following trauma. The injury has usually been severe and the skull fractured, the fracture generally involving the base. Thirst and polyuria begin a few days to several months after the injury. The severity of the symptoms varies from case to case, and may fluctuate in some patients. Fever sometimes improves the condition. The duration of the symptoms cannot be predicted, but most cases do recover. The response to pituitrin therapy is usually good, but sometimes symptoms are only partly relieved and in a few cases it has no effect. Other evidence of hypothalamic injury is sometimes present, a reduction in perspiration and obesity, and disturbance in sex functions. Cranial nerves are often involved, the optic and oculo-motor being those most commonly affected..

Of all non-fatal closed head injuries (gunshot wounds and those with dural penetrations excluded,) admitted to the Military Hospital for Head Injuries, Oxford, during the years 1940-45, which numbered about five thousand, thirteen suffered from diabetes insipidus. We have had the opportunity of studyingo three (Cases 5, 9, and 12) of these personally, the records of the other ten, and the records of five cases (Cases 14-18) treated in the Nuffield Depart ment of Surgery, Oxford, under Professor Sir Hugb $Z$ Cairns. This series of eighteen cases is reviewed in an attempt to add to our present rather inadequate knowledge of the clinical features and pathology of the condition.

The Table indicates the relevant features in each case.

Site of Trauma and Severity of Injury

The site of injury was judged by the position of cutaneous abrasions, bruises, or lacerations of the scalp or face, taking into consideration the position of fractures when present, and in all but three cases if was possible to determine with reasonable certainty the site at which the head was struck. In nine cases the blow was frontal, in six occipital. In twelve cases the skull was fractured-six in the frontal area, four in the occipital, and two in the middle fossa.

The severity of a closed head injury is difficult to assess and depends on several factors. The best single guide to severity, however, is the duration of the post-traumatic amnesia (P.T.A.) to which the degree of residual disability often bears a direct relationship, and Russell (1942) classifies cases with P.T.A. less than two hours as slight, two to fortyeight hours as moderate, and over two days as or severe. It is seen that the majority of our cases 
TABLE

DETAILS OF CASES

\begin{tabular}{|c|c|c|c|c|c|c|c|c|c|c|c|c|c|}
\hline \multirow[b]{2}{*}{$\begin{array}{l}\text { Case } \\
\text { No. }\end{array}$} & \multirow[b]{2}{*}{ Age } & \multirow[b]{2}{*}{$\begin{array}{l}\text { Nature of } \\
\text { injury and } \\
\text { date }\end{array}$} & \multirow[b]{2}{*}{$\begin{array}{l}\text { Site of } \\
\text { injury }\end{array}$} & \multirow[b]{2}{*}{$\begin{array}{c}\text { P.T.A. } \\
\text { in } \\
\text { days }\end{array}$} & \multicolumn{4}{|c|}{ Diabetes insipidus } & \multirow[b]{2}{*}{$\begin{array}{c}\text { Associated } \\
\text { hypo- } \\
\text { thalamic } \\
\text { or pituitary } \\
\text { disorder }\end{array}$} & \multicolumn{3}{|c|}{$\begin{array}{l}\text { Associated } \\
\text { injury to }\end{array}$} & \multirow[b]{2}{*}{ Radiograph of skull } \\
\hline & & & & & $\begin{array}{c}\text { Day of } \\
\text { onset } \\
\text { after } \\
\text { injury }\end{array}$ & $\mid \begin{array}{c}\text { Dura- } \\
\text { tion } \\
\text { (months) }\end{array}$ & $\begin{array}{c}\text { Maximum } \\
\text { recorded } \\
\text { 24-hour } \\
\text { output } \\
\text { of urine } \\
\text { (oz.) }\end{array}$ & $\begin{array}{c}\text { Response } \\
\text { to } \\
\text { pituitrin }\end{array}$ & & 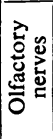 & : & : & \\
\hline 1 & 27 & $\begin{array}{l}\text { Motor cycle } \\
\text { accident } \\
16.3 .40\end{array}$ & Occipital & 19 & 9 & 1 & $150+$ & Yes & - & + & - & - & Nothing abnormal \\
\hline 2 & 21 & $\begin{array}{l}\text { Motor car } \\
\text { accident } \\
6.11 .42\end{array}$ & Frontal & 24 & 16 & $5 / 30$ & $150+$ & Yes & - & - & - & - & Nothing abnormal \\
\hline 3 & 20 & $\begin{array}{c}\text { Lorry accident } \\
20.10 .42\end{array}$ & Occipital & 7 & 31 & 1 & 180 & Yes & - & + & + & - & Nothing abnormal \\
\hline 4 & 19 & $\begin{array}{c}\text { Road accident } \\
20.10 .41\end{array}$ & Occipital & 17 & 12 & 1 & $200+$ & Unknown & $\begin{array}{c}\text { Pathological } \\
\text { laughter }\end{array}$ & - & - & - & $\begin{array}{l}\text { Vertical fissured fracture } \\
\text { occipital }\end{array}$ \\
\hline 5 & 27 & $\begin{array}{l}\text { Motor car } \\
\text { accident } \\
15.6 .45\end{array}$ & Frontal & 21 & 18 & 4 & 362 & Yes & - & + & - & + & $\begin{array}{l}\text { Fracture roof of right } \\
\text { orbit running into } \\
\text { frontal sinus; frac- } \\
\text { ture nasal bones }\end{array}$ \\
\hline 6 & 19 & $\begin{array}{l}\text { Fall } 30 \mathrm{ft} \text {. } \\
25.2 .41\end{array}$ & Frontal & 21 & 15 & 5 & 280 & Yes & - & + & - & + & $\begin{array}{l}\text { Fissured fracture frontal } \\
\text { involving sinus }\end{array}$ \\
\hline 7 & 20 & $\begin{array}{c}\text { Aeroplane } \\
\text { crash } \\
10.4 .43\end{array}$ & Unknown & $\begin{array}{l}5 \\
T\end{array}$ & 10 & 2 & $?$ & Yes & - & - & - & - & Nothing abnormal \\
\hline 8 & 26 & $\begin{array}{c}\text { Lorry accident } \\
28.7 .42\end{array}$ & Frontal & $2 / 24$ & 14 & $6 \frac{1}{3}$ & 250 & Yes & - & + & - & - & $\begin{array}{l}\text { Fractured right frontal } \\
\text { involving sinus }\end{array}$ \\
\hline 9 & 39 & $\begin{array}{c}\text { Bomb blast : } \\
\text { thrown forward } \\
8.4 .41\end{array}$ & Frontal & 13 & 13 & 9 & $?$ & Unknown & $\begin{array}{l}\text { Adiposo- } \\
\text { genital } \\
\text { syndrome }\end{array}$ & + & - & - & Nothing abnormal \\
\hline 10 & 38 & $\begin{array}{l}\text { Fell backward } \\
\text { striking head } \\
\text { on stone floor }\end{array}$ & Occipital & 10 & 10 & 7 & $150+$ & Yes & - & + & - & - & $\begin{array}{l}\text { Fissured fracture left } \\
\text { occipital }\end{array}$ \\
\hline 11 & 37 & $\begin{array}{c}\text { Road accident } \\
28.10 .44\end{array}$ & Occipital & $>21$ & 17 & $>22$ & 200 & Yes & $\begin{array}{c}\text { Outbursts of } \\
\text { rage }\end{array}$ & - & - & - & $\begin{array}{c}\text { Fissured fracture left } \\
\text { occipito-parietal }\end{array}$ \\
\hline 12 & 34 & $\begin{array}{c}\text { Car accident } \\
12.10 .45\end{array}$ & Frontal & 7 & 30 & $>13$ & 350 & Yes & $\begin{array}{l}\text { Anterior } \\
\text { pituitary } \\
\text { deficiency }\end{array}$ & - & - & + & Nothing abnormal \\
\hline 13 & 36 & $\begin{array}{c}\text { Car accident } \\
19.11 .40\end{array}$ & Frontal & 2 & 11 & $>38$ & 465 & Yes & - & + & - & - & $\begin{array}{l}\text { Fissured fracture left } \\
\text { frontal ; both max- } \\
\text { illz and right } \\
\text { zygoma }\end{array}$ \\
\hline 14 & 27 & $\underset{6.7 .44}{\text { Road accident }}$ & Occipital & 3 & $?$ & $>15$ & $?$ & Unknown & - & + & - & - & $\begin{array}{l}\text { Vertical fissured fracture } \\
\text { occipital into foramen } \\
\text { magnum }\end{array}$ \\
\hline 15 & 20 & $\begin{array}{l}\text { Bomb blast } \\
15.7 .44\end{array}$ & Frontal & 5 & 7 to 14 & $>12$ & 500 & Yes & - & - & - & - & Fissured fracture frontal \\
\hline 16 & 22 & $\begin{array}{c}\text { Fall from bus } \\
2.5 .44\end{array}$ & Unknown & 10 & 14 to & $>30$ & 600 & Yes & 一 & - & - & - & $\begin{array}{l}\text { Fissured fracture tem- } \\
\text { poral running into } \\
\text { middle fossa }\end{array}$ \\
\hline 17 & 30 & $\underset{1935}{\text { Car accident }}$ & Frontal & 21 & ? & $>96$ & 400 & Yes & - & + & - & + & $\begin{array}{l}\text { Fissured frontal fracture } \\
\text { maxilla and mandible }\end{array}$ \\
\hline 18 & 19 & $\begin{array}{c}\text { Car accident } \\
22.9 .38\end{array}$ & Unknown & 21 & $?$ & 2 & 320 & Unknown & - & + & - & + & $\begin{array}{l}\text { Bridged bella ? inter- } \\
\text { ruption in continuity } \\
\text { of petro-clinoid liga- } \\
\text { ments }\end{array}$ \\
\hline
\end{tabular}


suffered very severe injuries. In five only was the P.T.A. less than one week, and in only one of these was it less than two days.

\section{Onset, Course, and Treatment of Diabetes Insipidus}

Accuracy in determining the time of onset of diabetes insipidus is difficult, since so often the patients are confused and incontinent in the early stages after the injury. Moreover, limitation of fluid intake, which occurs if the patient is unable to demand extra drink, masks the condition. The symptoms were first noticed by the staff, or complained of by the patients, from nine to thirty-one days after the injury. In six cases the diagnosis was made with the aid of fluid intake and output charts before the period of post-traumatic amnesia was judged to have ended, and in two cases it was diagnosed on the day it ended. It might be argued that in these cases it had been present since the injury, but unnoticed. In the remaining five cases it was possible to estimate the time of onset more accurately, because there was a clear interval of from five to twenty-two days during which the patients were fully orientated and rational, before they complained of symptoms. There was, therefore, in these cases, a definite delay in the onset of the disease.

The degree of polyuria and polydipsia may at first be mild, and may reach the maximum days or even weeks later. Precise information is not available in most of our cases regarding fluctuations in the severity of the condition, because the natural course of the disease was usually altered by therapy. In three cases, however, we have information concerning the development of the disease. The symptoms were first noticed in one (Case 5) eighteen days after the injury, when the urinary output was $160 \mathrm{oz}$; it gradually increased, and reached the maximum recorded output of $362 \mathrm{oz}$. four days later, when treatment with pituitrin was started. In Case 12 the measured urinary output showed a steady increase to a maximum of $400 \mathrm{oz}$. eight days after the onset of symptoms. The third (Case 8) was noticed to have excessive thirst and increased urinary output, $160 \mathrm{oz}$. fourteen days after the injury, but it was not till five and a half weeks later that he complained of symptoms, by which time the output of urine had shown a steady increase to $250 \mathrm{oz}$. and treatment was started.

The course of the disease varied in severity and duration. The majority, eleven, recovered spontaneously within nine months of the onset. Of the remaining seven cases, one (Case 14) was improving and had only mild symptoms fifteen months after the onset, and the other six showed no sign of recovery. Three of the unchanged cases (Cases $11, \mathbb{\mathbb { D }}$ 12 , and 15) were observed for thirteen to twentytwo months. In the other three cases (Cases 13, क 16 , and 17) with persistent diabetes, the disease was $\stackrel{0}{0}$ considered to be permanent as it had been present $D$ for longer than two and a half, three, and eight years respectively.

Fourteen cases were treated with posterior pituitary extract, either hypodermically or as snuff, and complete relief of symptoms resulted in all of them, $\vec{F}$ provided adequate dosage was used. The response $\frac{7}{7}$ to pituitary therapy is not known in four cases, either because recovery had occurred (Cases 9 and $\overline{\overline{0}}$ 18) before the patients came under observation, or $\frac{\Phi}{\sigma}$ because treatment was considered unnecessary as $\frac{\varrho}{0}$ improvement was already taking place and symp- $\mathcal{\infty}$ toms were not troublesome (Cases 4 and 14). No $\overrightarrow{0}$ cases resistant to pituitrin were encountered.

\section{Associated Intracranial Damage}

Injuries to the olfactory nerves and optic chiasm or nerves were striking in their frequency. More than half (eleven cases) suffered from bilateral $\vec{A}$ anosmia, five had visual field defects characteristio i of a chiasmal lesion, and one had damage to the $\infty$ right optic nerve. No other signs of focal intres 을 cranial damage were common, and evidence of hypothalamic disorder, other than diabetes insipidus $z$ was uncommon. One patient only (Case presented other undoubted evidence of hypothalami $\frac{\Phi}{3}$ dysfunction, an adiposo-genital syndrome, which 앰 gradually developed during the first fifteen month following the injury. Two cases (Cases 4 and 1 I) showed emotional abnormality of a type which suggested a hypothalamic lesion, and in one case (Case 12) there was evidence of anterior pituitary dysfunction.

The infrequency of other hypothalamic syndromes following head injury is remarkable. When $\stackrel{\varnothing}{\varnothing}$ the material for this study was being collected, the $\overrightarrow{\vec{O}}$ records of all surviving cases of closed head injury at the Hospital for Head Injuries that had been indexed as having evidence of hypothalamic damage were examined, and all thirteen were found to have diabetes insipidus. Minor or transitory manifestations of hypothalamic disorder may have been missed, but it is highly improbable that such conditions as narcolepsy, impotence, or adiposogenital syndrome would have been overlooked, even if they occurred as late symptoms, since the majority of cases have been followed up for more than two years and many for four years.

\section{Comment}

Riddoch (1938) and Symonds (1943) have stated that diabetes insipidus is the most common disorder 
of hypothalamic function following closed head injury, and the evidence in this series strongly supports this view. It usually follows severe trauma to the front or back of the head, the same type of injury which has previously been shown to result most commonly in damage to the olfactory nerves, optic chiasm and nerves (Russell, 1943 ; Leigh, 1943 ; Traquair and others, 1935 ; Turner, 1943).

There appears to be no relationship between the severity of the injury and the delay in onset of the diabetes insipidus or its duration.

Although the precise mode of action of the posterior pituitary anti-diuretic hormone is not understood, there is general agreement that the gland is stimulated to secrete by nerve impulses passing to it from the supra-optic and paraventricular nuclei in the anterior hypothalamus via the supra-optic hypophyseal tract in the pituitary stalk. Experimentally, it has been shown that a bilateral lesion of these neurones is necessary for the production of diabetes insipidus (Fisher and others, 1938 ; Heinbecker and White, 1941 ; Magoun and Ranson, 1939). In these cases the polyuria is controlled by pituitrin, and Dandy (1940) has shown that section of the pituitary-stalk in man can result in permanent diabetes insipidus which responds to pitruitin. There are rare cases of diabetes insipidus unresponsive to pituitrin which Dreyfus (1931) suggested occurred only when the tubero-mamillary nuclei are damaged.

In experimentally produced diabetes insipidus there is a delay in onset of the permanent polyuria, usually six to twenty-two days (Biggart and Alexander, 1939 ; Fisher and others, 1938 ; Heinbecker and White, 1941), but it may be as long as six or ten weeks (Fisher and others, 1938). Heinbecker and White (1941) have shown in dogs that this delay can be abolished by removing all the pitressinsecreting tissue at operation, this suggesting that the latent period represents the time during which the denervated neuro-hypophysis produces pitressin. They also showed that the severity of the polyuria depended on the extent of damage to the supraoptic hypophyseal connexions, maximum and permanent polyuria following complete section; but, provided 15 per cent. of the fibres remained intact, the dogs recovered from their diabetes insipidus.

Holbourn (1943), in his studies on the mechanism of head injury, stresses the importance of changes in rotational velocity of the head, drawing the analogy of a full flask of water suddenly rotated, when it can easily be seen that the water tends to stay behind and only the flask rotates. Russell (1932) has suggested that movement of the brain relative to the skull at the time of injury may account for the frequency of anosmia in occipital injuries from tearing of olfactory filaments as they pass through the cribiform plate of the ethmoid. Traquair and others (1935) consider that the same mechanism may account for chiasmal lesions through the tearing of the small pial blood vessels supplying the chiasma. They also suggest that hypothalamic. lesions may be produced in this way. It would seem likely, however, that in such an antero-posterior displacement or rotation of the brain within the skull the supra-optic hypophyseal connexions lying superficially in the anterior hypothalamus and in the pituitary stalk might be injured by being stretched, since the pituitary is held rigidly in the sella turcica.

There is no doubt that in the present series of cases the onset of diabetes insipidus was delayed, and this might suggest that the neurones are not damaged at the time of injury but are interfered with by a delayed pathological process, for example, organizing blood clot round the pituitary stalk on pressure from an arachnoid cyst (Kourilsky and others, 1942). However, the delay in onset is consistent with experimental observation and does not rule out neuronal damage at the time of injury. It is interesting to notice in this connexion that the period of delay in our cases corresponds fairly closely to that found in experimental animals.

The pathology probably varies in different cases. Laceration of the hypothalamus or pituitary by a displaced fragment of bone, or tearing by separation of a fracture of the sphenoid, are very improbable in our cases, for in none was there radiological evidence of a fracture involving the sphenoid or of a displaced bone fragment at the base of the brain. Interference with the blood supply to the hypothalamus from tearing of the fine pial vessels might account for some cases, but if this were a usual mechanism it would be strange that other hypothalamic syndromes are not encountered more frequently. An arachnoid cyst in the chiasmal region has been found at operation to be the cause of diabetes insipidus (Kourilsky and others, 1942), and the symptoms have been relieved immediately by incision of the cyst. However, one would expect pressure from a cyst or constriction of the pituitary stalk from organized blood clot to result in a permanent diabetes insipidus unless the pressure were relieved surgically, and it is seen that the majority of cases undergo spontaneous recovery within nine months. We think it probable, therefore, that the lesion is most commonly in the pituitary stalk, due to stretching from displacement of the brain at the time of injury, and that the duration of symptoms and severity of the diabetes 
insipidus may depend on the extent of neuronal damage in the supra-optic-hypophyseal tract. The rarity of other hypothalamic syndromes and of permanent refractory diabetes insipidus is probably due to the high mortality rate from more extensive injury to this part of the brain.

\section{Summary}

1. Eighteen cases of diabetes insipidus following closed head injury have been studied and the relevant features tabulated.

21. In fifteen in which the site of injury could be determined it was frontal or occipital.

3. The symptoms were usually first noticed during the second or third week after injury.

4. All cases treated responded to pituitrin.

5. Spontaneous recovery took place in the majority, in eleven within nine months.

6. Associated injury to the olfactory nerves and optic chiasm is common; other hypothalamic syndromes are rare.

7. The mechanism of the injury is discussed, and it is suggested that a traction lesion of the pituitary stalk would best explain most cases.

We are greatly indebted to Dr. Ritchie Russell for his help and encouragement with this paper, and to Professor Sir Hugh Cairns for permission to use his case records.

\section{REFERENCES}

Beattie, J. (1938). In Clark, W. E. Le Gros, and others : "The Hypothalamus." Oliver. Boro, Edinburgh. p. 69.

Biggart, J. H., and Alexander, G. L. (1939). J. Path. Baç., 48, 405.
Dandy, W. E. (1940). J. Amer. med. Ass., 114, 312.

Dreyfus, G. G. (1931). "Le Diabete Insipide." Doin, Paris. Quoted by Beattie.

Fink, E. B. (1928). Arch. Path., 6, 102.

Fisher, C., Ingram, W. R., and Ranson, S. W. (1938) "Diabetes Insipidus and the Neuro-Hormonal Control of Water Balance." Edwards Brothers, Inc., Ann Arbor, Michigan.

Fitz, R. (1914). Arch. intern. Med., 14, 706.

Heinbecker, P., and White, H. L. (1941). Amer. J. Physiol., 133, 582.

Holbourn, A. H. S. (1943). Lancet, $2,438$.

Jones, G. M. (1944). Arch. intern. Med., 74, 81.

Kahler, O. (1886). Z. Heilk., 7, 105. Quoted by Fink.

Kourilsky, R., David, M., Sicard, J., and Galey, J. J. (1942). Rev. Neurol., 74; 264.

Leigh, A. D. (1943). Lancet, 1, 38.

Magoun, H. W., and Ranson, S. W. (1939). Trans. Amer. Neurol. Ass., 65, 63.

Rabinowitch, I. M. (1921). Arch. intern. Med., 28, 355.

Rand, C. W., and Patterson; G: H. (1937). Bull. Los Angeles Neurol. Soc., 2, 163.

Riddoch, G. (1938). In Clark, W. E. Le Gros and others : "The Hypothalamus." Oliver. Boro, Edinburgh. p. 119.

Rowntree, L. G. (1924). J. Amer. med. Ass., 83, 399. Quoted by Rand and Patterson.

Rowbotham, S. F. (1945). "Acute Injuries of the Head." Second Edit. p. 300.

Russell, W. R. (1932). Brain, 55, 549.

(1943). In Brock's "Injuries of the Skull, Brain, and Spinal Cord." London. p. 104. (1942). Brit. med. J., 2, 521.

Symonds, C. P. (1943). In Brock's "Injuries of the Skull, Brain, and Spinal Cord." London. p. 65.

Traquair, H. M., Dott, N. M., and Russell, W. R.g (1935). Brain, 58, 398.

Turner, J. H. (1928). Arch. Pediat., 45, 433.

Turner, J. W. A. (1943). Brain, 66, 140.

Warkany, J., and Mitchell, A. G. (1939). Amer. Dis. Child., 57, 603. 